\title{
Synthesis and 1,3-Dipolar Cycloaddition Reactions of Chiral Maleimides
}

\author{
Vladimir Ondrus* and Lubor Fisera* \\ Department of Organic Chemistry, Slovak Technical University, SK-812 37 Bratislava, Slovak Republic, FAX +42 7368 \\ 560 (fisera@cvtstu.cvt.stuba.sk)
}

Received: 19 October 1996 / Accepted: 10 December 1996 / Published: 25 February 1997

\begin{abstract}
New routes to the synthesis of various novel chiral maleimides are described. The oxabicyclic anhydride 2 readily available exo-Diels-Alder adduct of furan and maleic anhydride was used as a vehicle, which in turn reacted with hydrochlorides of amino acids $\mathbf{3 a - f}$ in the presence of $\mathrm{Et}_{3} \mathrm{~N}$ with release of furan to give the requisite novel chiral imides $\mathbf{4 a - f}$ in good to moderate yields. The stereoselectivity of 1,3-dipolar cycloaddition of nitrile oxides with prepared chiral imides $\mathbf{4 a - f}$ is investigated.
\end{abstract}

Keywords: Chiral maleimides, 1,3-dipolar cycloadditions, nitrile oxides, stereoselectivity.

\section{Introduction}

Maleimides are an important class of substrates for biological and chemical applications. In biological applications they are used as chemical probes of protein structure [1], as immunoconjugates for cancer therapy, as solid supported enzymes for synthetic applications, as haptene for the production of antibodies [2] or as new herbicides and pesticides [3]. Some compounds of the dicarboxyimide type are reported to reveal effective systeme activity against Botrytis cinerea, Cochliobolus miyabeanus and Pellicularia sasaci [3]. N-(3,5Dichlorophenyl)pyrrolidine-2,5-dione (Dimetachlon) is being used as a protective and curative fungicide [4] and the cycloadduct of $\mathrm{N}$-(3,5-dichlorophenyl)maleimide to furan [5] and its derivatives have also considerable fungicidal properties. The maleimide moiety can be used as a platform in synthesis due to its Michael accepting ability, dienophilic nature [6,7] as well as to its reactivity as a dipolarophile in 1,3-dipolar cycloadditions [8].

* To whom correspondence should be addressed.
Despite this, there are few reports in the literature of the synthesis of $N$-substituted chiral maleimides. Most methods involve the reaction of an amine with maleic anhydride, followed by dehydration of the intermediate maleamic acid, usually promoted by acids [9]. This method is limited to the use of amines as starting material and excludes those, that are unstable to the dehydration conditions.

In our effort to investigate the stereoselectivity of cycloaddition reactions to heterocyclic compounds, we have paid attention to the simple and effective synthesis of novel chiral dipolarophiles. Biagini and co-workers [10] recently published a simple synthesis of amino acids derivatives 1, which contains in their skeleton the norbornenyl function. The authors describe two methods: a) a high temperature (one-pot) procedure and b) a low temperature (two steps) rout [10]. The second, milder method, allowed the synthesis of rather unstable products. All of the norbornenes $\mathbf{1}$ prepared in this way were optically active, providing the first indication that the 
relatively harsh reaction conditions had not caused complete racemisation of the amino acids $\alpha$-centre. On the basis of this report we have started to test some possibilities to find efficient methods to prepare the $N$ substituted chiral maleimides (Scheme 1).

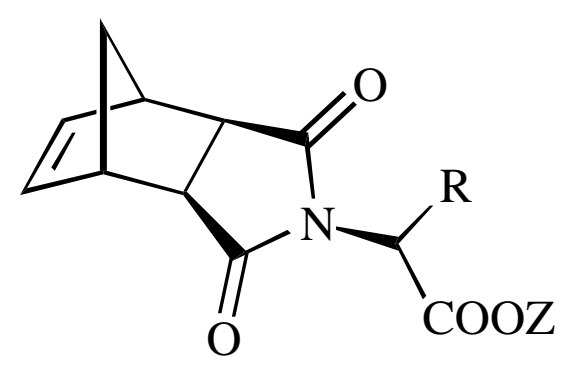

1

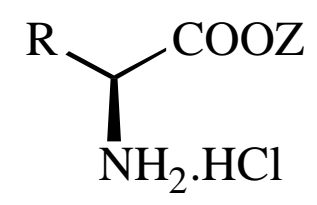

3a-f

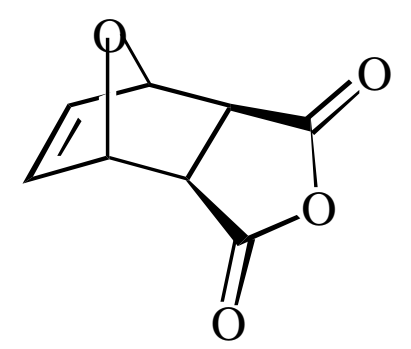

2<smiles>[R]OC(=O)C([R])N1C(=O)C=CC1=O</smiles>

4a-d<smiles>COC(=O)[C@H](Cc1c[nH]c2ccccc12)N1C(=O)C=CC1=O</smiles>

$4 \mathbf{f}$

a: $\mathrm{R}=\mathrm{CH}_{3}$, b: $\mathrm{R}=\left(\mathrm{CH}_{3}\right)_{2} \mathrm{CH}, \mathrm{c}: \mathrm{R}=\left(\mathrm{CH}_{3}\right)_{2} \mathrm{CHCH}_{2}$,

d: $\mathrm{R}=\mathrm{HOCH}_{2}$, e: $\mathrm{R}=\mathrm{CH}_{2} \mathrm{COOCH}_{2} \mathrm{CH}_{3}$,

For : $\mathbf{4 a}, \mathbf{b}, \mathbf{d}, \mathbf{e} \mathrm{Z}=\mathrm{CH}_{3} \mathrm{CH}_{2}, \mathbf{4} \mathbf{c} \mathrm{Z}=\mathrm{CH}_{3}$

Scheme 1.

\section{Results and Discussion}

We chose the oxabicyclic anhydride 2 , a readily available exo-Diels-Alder adduct of furan and maleic anhydride [11] as a vehicle, which in turn reacted with hydrochlorides of amino acids 3a-f in the presence of $\mathrm{Et}_{3} \mathrm{~N}$ with release of furan to give requisite novel chiral imides 4a-f in good to moderate yield (40-60\%, Scheme 2). Yields, reported for the detailed application of the Biagini method [10] (1 eq. of amino acids, $0.9-1$ eq. of 
oxabicyclic anhydride 2, $1.2-1.7$ eq. of $\mathrm{Et}_{3} \mathrm{~N}, 20$ - 29 h) were in all cases low (Table 1, Method A) and for $(S)$ alanine $\mathbf{4 a}$ and $(S)$-valine $\mathbf{4 b}$ derivatives this synthetic route was not successful. Only signals for the uncyclized form were detected in the ${ }^{1} \mathrm{H}$ NMR spectra after work-up.

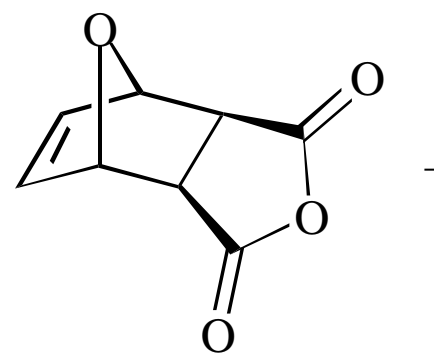

2<smiles>[R]C(N)C(=O)O[Na]</smiles>

3a-f

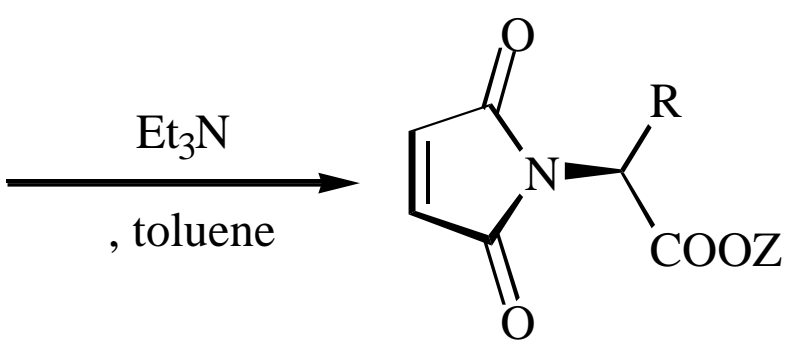

4a-f

Scheme 2. Synthesis of maleimides 4a-f.

Therefore we had to change this procedure. The prolongation of the reaction time (19-56 h, TLC monitoring) and the use of excess $\mathrm{Et}_{3} \mathrm{~N}$ (1.7-2 eq. of amino acids) resulted in increased yields. (Table 1, Method B). In contrast to the previously mentioned Method A, after completion of the reaction, the reaction mixture was purified by column chromatography. Thus, the yields of all derivatives were increased and we were also able to isolate $(S)$-alanine $\mathbf{4 a}$ and $(S)$-valine $\mathbf{4 b}$ maleimides, in moderate yield. This modification was also successful for the heterocyclic amino acid - $(S)$-tryptophane $\mathbf{4 f}$.
We performed this modified synthetic route for the direct synthesis of required compounds by the reaction of maleic anhydride with the hydrochloride salts of amino acids. In the cases of $(S)$-alanine $\mathbf{4 a}$ and $(S)$-valine $\mathbf{4 b}$ the high temperature procedure did not give the expected $N$ maleonyl derivative, but rather the intermediate amino acids were obtained. On the other hand, in the case of $(S)$ leucine and $(S)$-aspartic acid salts the substituted maleimides were isolated in spectroscopically pure form (Method C, Scheme 3).<smiles>O=C1CCC(=O)O1</smiles><smiles>[R]C(N)C(=O)O[Na]</smiles>

3a-f

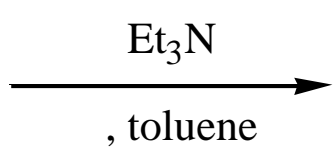

4a-f

Scheme 3. Synthesis of maleimides $\mathbf{4 a - f}$ by method C. 
Table 1. Yields of required maleimides related to synthetic method.

\begin{tabular}{llll}
\hline Compd. & $\begin{array}{l}\text { Method A } \\
\text { Yield (\%) }\end{array}$ & $\begin{array}{l}\text { Method B } \\
\text { Yield (\%) }\end{array}$ & $\begin{array}{l}\text { Method C } \\
\text { Yield (\%) }\end{array}$ \\
\hline 4a & $<5$ & 28 & $<5$ \\
$\mathbf{4 b}$ & $<5$ & 50 & $<5$ \\
$\mathbf{4 c}$ & 24 & 44 & 49 \\
$\mathbf{4 d}$ & 16 & $\mathrm{x}$ & $<5$ \\
$\mathbf{4 e}$ & 39 & 62 & 55 \\
$\mathbf{4 f}$ & $\mathrm{x}$ & 50 & $\mathrm{x}$ \\
\hline
\end{tabular}

$\mathrm{X}$ - this method was not tried
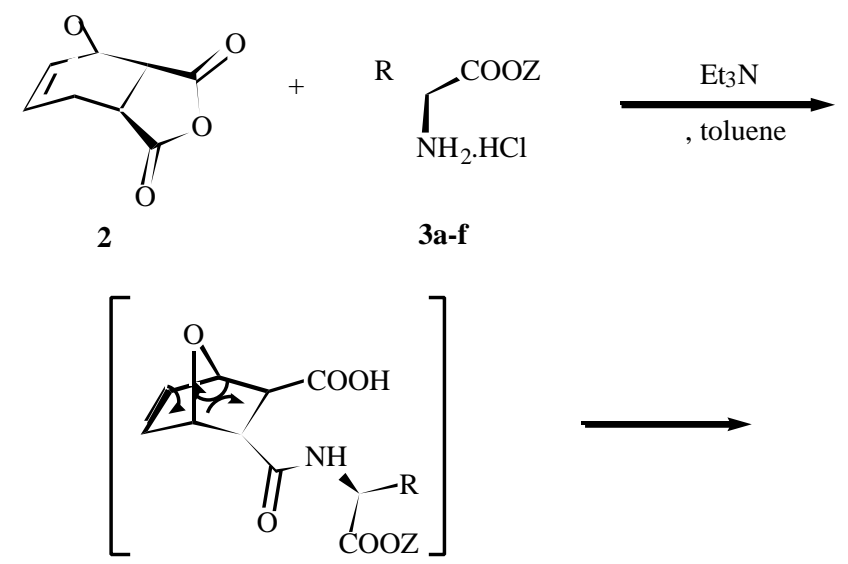

6<smiles>[R]C(=O)CN1C(=O)C=CC1O</smiles>

4a-f<smiles>[R]CNC(=O)/C=C/C(=O)O</smiles>

5a-f
Scheme 4. Formation of 4a-f and 5a-f.
As an additional product chiral fumaric acids $\mathrm{N}$ substituted amides 5 were formed (60-20\%) in all cases. The structure of $(E)-\mathbf{5}$ was confirmed by ${ }^{1} \mathrm{H}$ NMR spectroscopy. The value of the interaction constant $J$ 14-16 $\mathrm{Hz}$ was determined and clearly proved the trans arrangement of the olefinic protons.

We suppose, that at high temperature two competitive reactions are possible (Scheme 4). Uncyclized maleamic 6 derivative can cyclize, the corresponding oxabicyclic derivative can undergo a retro-Diels-Alder reaction, furan is evaporated and the required product $\mathbf{4}$ is formed. The intermediate $\mathbf{6}$ can izomerize to trans-6 to give the more stable $E$-isomer $\mathbf{5}$.

In an effort to prevent these concurrent reactions, we performed the reaction of $\mathbf{2}$ with the $(S)$-aspartic derivative in various solvents. Analysis of the NMR spectra of the crude reaction mixture showed, that in the case of $\mathrm{CH}_{2} \mathrm{Cl}_{2}$ as a solvent only signals for the uncyclized derivative $\mathbf{6}$ as well as signals for the starting bicyclic derivative $\mathbf{2}$ were detected and maleimide $\mathbf{4}$ was not formed. After heating in benzene only signals for the uncyclized intermediate 6 were confirmed. The useful synthetic scope of this reaction for the preparation of maleimide $\mathbf{4}$ is given at temperature over $90^{\circ} \mathrm{C}$.

Some 1,3-dipolar cycloaddition reactions were than tested with the prepared imides with the aim of investigating the stereocontrol of these additions. Two dipoles were chosen, the stable 2,4,6-trimethylphenylnitrile oxide [12] reacted by heating in benzene as well as benzenenitrile oxide generated from the corresponding benzhydroxymoyl chloride and $\mathrm{Et}_{3} \mathrm{~N}$ in the presence of imides. The mixture of stereoisomers 7 was prepared in only poor to moderate stereoselectivity (Scheme 5). The ratio of diastereoisomers 7 depends on the substituent on the maleimide skeleton (Table 2).<smiles>[R]OC(=O)C([R])N1C(=O)C=CC1=O</smiles>

4a-f

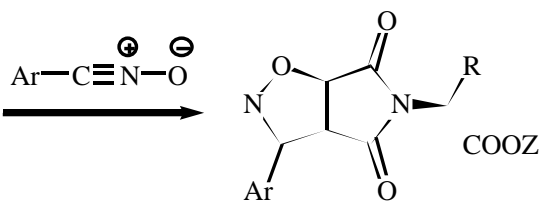

Scheme 5. Nitrile oxide cycloaddtions to $\mathbf{4 a - f}$. 
Table 2. Stereoselectivity of 1,3-dipolar cycloaditions of nitrile oxides to maleimides $\mathbf{4 a - f}$.

\begin{tabular}{lllll}
\hline Compound & $\mathbf{R}$ & $\mathbf{Z}$ & $\mathbf{A r}$ & $\begin{array}{l}\text { Ratio } \\
\text { endo / exo }\end{array}$ \\
\hline $\mathbf{4 a}$ & $\mathrm{CH}_{3}$ & $\mathrm{Et}$ & $\mathrm{Mst}$ & $75: 25$ \\
$\mathbf{4 b}$ & $\left(\mathrm{CH}_{3}\right)_{2} \mathrm{CH}$ & $\mathrm{Et}$ & $\mathrm{Mst}$ & $70: 30$ \\
$\mathbf{4 c}$ & $\left(\mathrm{CH}_{3}\right)_{2} \mathrm{CHCH}_{2}$ & $\mathrm{Me}$ & $\mathrm{Mst}$ & $64: 36$ \\
$\mathbf{4 c}$ & $\left(\mathrm{CH}_{3}\right)_{2} \mathrm{CHCH}_{2}$ & $\mathrm{Me}$ & $\mathrm{Ph}$ & $59: 41$ \\
$\mathbf{4 d}$ & $\mathrm{CH}_{2} \mathrm{OH}$ & $\mathrm{Et}$ & Mst & $59: 41$ \\
$\mathbf{4 e}$ & $\mathrm{CH}_{2} \mathrm{COOEt}$ & $\mathrm{Et}$ & Mst & $71: 29$ \\
$\mathbf{4 e}$ & $\mathrm{CH}_{2} \mathrm{COOEt}$ & $\mathrm{Et}$ & $\mathrm{Ph}$ & $72: 28$ \\
$\mathbf{4 f}$ & $3-$ Indolylmethyl & $\mathrm{Me}$ & Mst & $60: 40$ \\
\hline
\end{tabular}

\section{Conclusion}

A modified route for the synthesis of novel chiral maleimides has been developed. The synthetic pathway is short, using only readily available starting materials and reagents. 1,3-Dipolar cycloadditions of nitrile oxides proceeded with moderate diastereoselectivity and further improvement is currently in progress.

\section{Experimental}

\section{General}

${ }^{1} \mathrm{H}$ NMR spectra were recorded at $300 \mathrm{MHz}$ on a Varian VXR 300 or at $80 \mathrm{MHz}$ on a Tesla BS 487 at $293 \mathrm{~K}$ in $\mathrm{CDCl}_{3}$. Spectra were internally referenced to TMS. Peaks are reported in ppm downfield of TMS. Multiplicities are reported as singlet (s), doublet (d), triplet (t), quartet (q), some combination of these, broad (br), or multiplet $(\mathrm{m}) .{ }^{13} \mathrm{C}$ NMR spectra were recovered at 75.0 $\mathrm{MHz}$ on the same spectrometer as ${ }^{1} \mathrm{H}$ NMR spectra at 293 $\mathrm{K}$ in $\mathrm{CDCl}_{3}$. Peak assignments were made by DEPT editing of the spectra, and a * indicates that peak assignments may be interchanged. Optical rotations were recorded on POLAR L- $\mu$ P (IBZ Messtechnik) polarimeter and are reported along with solvent and concentration in g/100ml. Flash chromatography was carried out on 63-200 $\mu \mathrm{m}$ or $40-60 \mu \mathrm{m}$ silica gel, thin layer chromatography was carried out on aluminium backed silica plates containing $\mathrm{UV}_{254}$ by Lachema and plates were visualised with UV light and Mostaine solution as appropriate. New compounds were characterised by their elemental compositions established by combustion analysis. All yields refer to isolated, spectroscopically pure material, and have not been optimised.

\section{$N$-Maleonyl-(S)-alanine ethyl ester $\mathbf{4 a}$}

\section{Method B}

To a solution of exo-7-oxohimic acid anhydride (1.00 $\mathrm{g}, 6.01 \mathrm{mmol})$ and $\mathrm{Et}_{3} \mathrm{~N}(2.00 \mathrm{ml}, 14.0 \mathrm{mmol})$ dissolved in toluene $\left(50 \mathrm{~cm}^{3}\right)$ was added $(S)$-alanine ethyl ester hydrochloride $(1.41 \mathrm{~g}, 7.00 \mathrm{mmol})$ and the resulting mixture was stirred at $110^{\circ} \mathrm{C}$ for 19 hours. The solution was cooled to room temperature, diluted with ethyl acetate $\left(20 \mathrm{~cm}^{3}\right)$ and filtered. The filtrate was evaporated in vacuo, and the residue purified by column chromatography (eluent chloroform-methanol 10:1, $40 \mathrm{~g}$ silica gel 40-60 $\mu \mathrm{m}$ mesh, $30 \times 2.5 \mathrm{~cm})$ to give the title compound $4 \mathbf{a}(330 \mathrm{mg}, 28 \%)$ as a pale yellow oil, $[\alpha]_{\mathrm{D}}^{2 \mathrm{~b}}=-27.3^{\circ}\left(\mathrm{c}=0.11, \mathrm{CH}_{2} \mathrm{Cl}_{2}\right)$.

${ }^{1} \mathrm{H}$ NMR (300 MHz; $\left.\mathrm{CDCl}_{3}\right) 1.25\left(3 \mathrm{H}, \mathrm{t}, \mathrm{OCH}_{2} \mathrm{CH}_{3}\right)$, $1.62\left(3 \mathrm{H}, \mathrm{d}, J 7.3 \mathrm{~Hz}, \mathrm{CH}_{3}\right), 4.18\left(2 \mathrm{H}, \mathrm{q}, \mathrm{OCH}_{2} \mathrm{CH}_{3}\right), 4.75$ $(1 \mathrm{H}, \mathrm{q}, J 7.5 \mathrm{~Hz}, \mathrm{~N}-\mathrm{CH}), 6.75(2 \mathrm{H}, \mathrm{s},=\mathrm{CH})$.

\section{$N$-Maleonyl-(S)-valine-ethyl ester $\mathbf{4 b}$}

\section{Method B}

To a solution of exo-7-oxohimic acid anhydride (750 $\mathrm{mg}, 4.50 \mathrm{mmol})$ and $\mathrm{Et}_{3} \mathrm{~N}(1.53 \mathrm{ml}, 11.0 \mathrm{mmol})$ dissolved in toluene $\left(50 \mathrm{~cm}^{3}\right)$ was added $(S)$-valine ethyl ester hydrochloride $(1.00 \mathrm{~g}, 5.50 \mathrm{mmol})$ and the resulting mixture was stirred at $110^{\circ} \mathrm{C}$ for 36 hours. The solution was cooled to room temperature, diluted with ethyl acetate $\left(20 \mathrm{~cm}^{3}\right)$ and filtered. The filtrate was evaporated in vacuo, 
and the residue purified by column chromatography (eluent dichloromethane-methanol 12:1, 40g silica gel 40-60 $\mu \mathrm{m}$ mesh, $30 \times 2.5 \mathrm{~cm})$ to give the title compound $\mathbf{4 b}(500 \mathrm{mg}$, $50 \%)$ as a yellow oil, $[\alpha]_{\mathrm{D}}^{2 b}=-14.7^{\circ}\left(\mathrm{c}=0.15, \mathrm{CH}_{2} \mathrm{Cl}_{2}\right)$.

${ }^{1} \mathrm{H}$ NMR $\left(300 \mathrm{MHz}: \mathrm{CDCl}_{3}\right) 0.87(3 \mathrm{H}, \mathrm{d}, J 6.8 \mathrm{~Hz}$, $\left.\mathrm{CH}_{3}\right), 1.08\left(3 \mathrm{H}, \mathrm{d}, J 6.7 \mathrm{~Hz}, \mathrm{CH}_{3}\right), 1.23(3 \mathrm{H}, \mathrm{t}$, $\left.\mathrm{OCH}_{2} \mathrm{CH}_{3}\right), 2.66(1 \mathrm{H}, \mathrm{m}, \mathrm{CH}), 4.17\left(2 \mathrm{H}, \mathrm{q}, \mathrm{OCH}_{2} \mathrm{CH}_{3}\right)$, $4.38(1 \mathrm{H}, \mathrm{d}, J 8.1 \mathrm{~Hz}, \mathrm{~N}-\mathrm{CH}), 6.79(2 \mathrm{H}, \mathrm{s},=\mathrm{CH})$.

${ }^{13} \mathrm{C}$ NMR (75 MHz; $\left.\mathrm{CDCl}_{3}\right) 14.07$ (q, $\left.\mathrm{OCH}_{2} \mathrm{CH}_{3}\right)$, 19.37 (q, $\mathrm{CH}_{3}$ ), 20.99 (q, $\mathrm{CH}_{3}$ ), 28.47 (d, CH), 57.98 (d, $\mathrm{N}-\mathrm{CH}), 61.43$ (t, $\left.\mathrm{OCH}_{2} \mathrm{CH}_{3}\right), 134.21(\mathrm{~d},=\mathrm{CH}), 168.62$ (s, $\mathrm{C}=\mathrm{O}), 170.22(\mathrm{~s}, \mathrm{C}=\mathrm{O})$.

\section{$N$-Maleonyl-(S)-leucine-methyl ester $\mathbf{4 c}$}

\section{Method A}

To a solution of exo-7-oxohimic acid anhydride $(2.00$ $\mathrm{g}, 12.0 \mathrm{mmol})$ and $\mathrm{Et}_{3} \mathrm{~N}\left(2.10 \mathrm{~cm}^{3}, 15.0 \mathrm{mmol}\right)$ dissolved in toluene $\left(100 \mathrm{~cm}^{3}\right)$ was added $(S)$-leucine methyl ester hydrochloride $(2.15 \mathrm{~g}, 12.0 \mathrm{mmol})$ and the resulting mixture was stirred at $110^{\circ} \mathrm{C}$ for 20 hours. The solution was cooled to room temperature, diluted with ethyl acetate $\left(20 \mathrm{~cm}^{3}\right)$, filtered and the filtrate was washed with $2 \mathrm{M} \mathrm{HCl}$ $\left(3 \times 20 \mathrm{~cm}^{3}\right)$ and the aqueous phase back extracted with ethyl acetate $\left(3 \times 30 \mathrm{~cm}^{3}\right)$. The combined organic layer was dried $\left(\mathrm{MgSO}_{4}\right)$ and the solvent was evaporated in vacuo. Purification by column chromatography (eluent chloroform, $40 \mathrm{~g}$ silica gel $40-60 \mu \mathrm{m}$ mesh, $30 \times 2.5 \mathrm{~cm})$ to leave the title compound $\mathbf{4 c}(640 \mathrm{mg}, 24 \%)$ as a colourless oil, which solidified on standing. $[\alpha]_{\mathrm{D}}^{25}=-13.0^{\circ}(\mathrm{c}=0.1$, $\mathrm{CH}_{2} \mathrm{Cl}_{2}$ ).

\section{Method B}

To a solution of exo-7-oxohimic acid anhydride (1.00 $\mathrm{g}, 6.01 \mathrm{mmol})$ and $\mathrm{Et}_{3} \mathrm{~N}\left(2.00 \mathrm{~cm}^{3}, 14.0 \mathrm{mmol}\right)$ dissolved in toluene $\left(40 \mathrm{~cm}^{3}\right)$ was added $(S)$-leucine methyl ester hydrochloride $(1.27 \mathrm{~g}, 7.00 \mathrm{mmol})$ and the resulting mixture was stirred at $110^{\circ} \mathrm{C}$ for 38 hours. The solution was cooled to room temperature, diluted with ethyl acetate $\left(20 \mathrm{~cm}^{3}\right)$ and filtered. The filtrate was evaporated in vacuo, and the residue purified by column chromatography (eluent dichloromethane-methanol 12:1, $60 \mathrm{~g}$ silica gel 40-60 $\mu \mathrm{m}$ mesh, 40x2 cm) to give the title compounds $4 \mathrm{c}(602 \mathrm{mg}$, $44 \%$ ) as a colourless oil.

\section{Method C}

To a solution of maleic anhydride $(503 \mathrm{mg}, 5.09 \mathrm{mmol})$ and $\mathrm{Et}_{3} \mathrm{~N}\left(1.05 \mathrm{~cm}^{3}, 7.50 \mathrm{mmol}\right)$ dissolved in toluene $(50$ $\left.\mathrm{cm}^{3}\right)$ was added $(S)$-leucine methyl ester hydrochloride $(1.10 \mathrm{~g}, 6.00 \mathrm{mmol})$ and the resulting mixture was stirred at $110^{\circ} \mathrm{C}$ for 46 hours. The solution was cooled to room temperature, diluted with ethyl acetate $\left(20 \mathrm{~cm}^{3}\right)$ and filtered. The filtrate was evaporated in vacuo, and the residue purified by column chromatography (eluent chloroform-metanol 12:1, $60 \mathrm{~g}$ silica gel 40-60 $\mu \mathrm{m}$ mesh, $40 \times 2 \mathrm{~cm}$ ) to give the title compound $4 \mathrm{c}(570 \mathrm{mg}, 49 \%)$ as a colourless oil.

${ }^{1} \mathrm{H}$ NMR (300 MHz: $\left.\mathrm{CDCl}_{3}\right) 0.90(3 \mathrm{H}, \mathrm{d}, J 6.6 \mathrm{~Hz}$, $\left.\mathrm{CH}_{3}\right), 0.94\left(3 \mathrm{H}, \mathrm{d}, J 6.6 \mathrm{~Hz}, \mathrm{CH}_{3}\right), 1.42(1 \mathrm{H}, \mathrm{m}, \mathrm{CH}), 1.85$ $\left(1 \mathrm{H}\right.$, ddd, $\left.J 14.2,11.7,4.7 \mathrm{~Hz}, \mathrm{CH}_{2}\right), 2.25\left(1 \mathrm{H}, \mathrm{ddd}, \mathrm{CH}_{2}\right)$, $3.72\left(3 \mathrm{H}, \mathrm{s}, \mathrm{OCH}_{3}\right), 4.75(1 \mathrm{H}, \mathrm{dd}, J 11.7,4.3 \mathrm{~Hz}, \mathrm{~N}-\mathrm{CH})$, $6.75(2 \mathrm{H}, \mathrm{s},=\mathrm{CH})$.

${ }^{13} \mathrm{C} \mathrm{NMR}\left(75 \mathrm{MHz}: \mathrm{CDCl}_{3}\right) 20.90\left(\mathrm{q}, \mathrm{CH}_{3}\right), 23.10(\mathrm{q}$, $\left.\mathrm{CH}_{3}\right), 25.02(\mathrm{~d}, \mathrm{CH}), 37.06\left(\mathrm{t}, \mathrm{CH}_{2}\right), 50.54(\mathrm{~d}, \mathrm{~N}-\mathrm{CH})$, $52.73\left(\mathrm{q}, \mathrm{OCH}_{3}\right), 134.29$ (d, =CH), 170.17 (s, C=O).

\section{N-Maleonyl-(S)-serine- ethyl ester $4 d$}

Method A

To a solution of exo-7-oxohimic acid anhydride (2.00 g, $12.0 \mathrm{mmol})$ and $\mathrm{Et}_{3} \mathrm{~N}\left(2.10 \mathrm{~cm}^{3}, 15.0 \mathrm{mmol}\right)$ dissolved in toluene $\left(100 \mathrm{~cm}^{3}\right)$ was added $(S)$-serine ethyl ester hydrochloride $(2.04 \mathrm{~g}, 12.0 \mathrm{mmol})$ and the resulting mixture was stirred at $110^{\circ} \mathrm{C}$ for 24 hours. The solution was cooled to room temperature, diluted with ethyl acetate $\left(20 \mathrm{~cm}^{3}\right)$, filtered and the filtrate was washed with $2 \mathrm{M} \mathrm{HCl}$ $\left(3 \times 20 \mathrm{~cm}^{3}\right)$ and the aqueous phase back extracted with ethyl acetate $\left(3 \times 30 \mathrm{~cm}^{3}\right)$. The combined organic layer was dried $\left(\mathrm{MgSO}_{4}\right)$ and the solvent was evaporated in vacuo to leave the title compound $\mathbf{4 d}$ (404 $\mathrm{mg}, 16 \%$ ) as a colourless oil.

${ }^{1} \mathrm{H}$ NMR (300 MHz; $\left.\mathrm{CDCl}_{3}\right) 1.25\left(3 \mathrm{H}, \mathrm{t}, \mathrm{OCH}_{2} \mathrm{CH}_{3}\right)$, $3.24(1 \mathrm{H}$, brs, $\mathrm{OH}), 4.12\left(2 \mathrm{H}, \mathrm{m}, \mathrm{CH}_{2}\right), 4.22(2 \mathrm{H}, \mathrm{d}, J$ 7.2, $\left.\mathrm{OCH}_{2} \mathrm{CH}_{3}\right), 4.82(1 \mathrm{H}, \mathrm{t}, \mathrm{N}-\mathrm{CH}), 6.81(2 \mathrm{H}, \mathrm{s},=\mathrm{CH})$.

$\left.{ }^{13} \mathrm{C} \mathrm{NMR} \mathrm{(300} \mathrm{MHz:} \mathrm{CDCl}_{3}\right) 14.04\left(\mathrm{q}, \mathrm{OCH}_{2} \mathrm{CH}_{3}\right)$, $54.66(\mathrm{~d}, \quad \mathrm{~N}-\mathrm{CH}), \quad * 60.53 \quad\left(\mathrm{t}, \quad \mathrm{CH}_{2} \mathrm{OH}\right), \quad * 62.53$ $\left(\mathrm{t}, \mathrm{OCH}_{2} \mathrm{CH}_{3}\right), 134.53(\mathrm{~d},=C \mathrm{H}), 167.81(\mathrm{~s}, \mathrm{C}=\mathrm{O}), 170.52$ (2s, $\mathrm{C}=\mathrm{O})$.

\section{N-Maleonyl-(S)-aspartic acid diethyl ester $4 \boldsymbol{e}$}

Method A

To a solution of exo-7-oxohimic acid anhydride (1.00 $\mathrm{g}, 6.01 \mathrm{mmol})$ and $\mathrm{Et}_{3} \mathrm{~N}\left(1.70 \mathrm{~cm}^{3}, 12.0 \mathrm{mmol}\right)$ dissolved in toluene $\left(100 \mathrm{~cm}^{3}\right)$ was added $(S)$-aspartic acid diethyl ester hydrochloride $(1.58 \mathrm{~g}, 7.00 \mathrm{mmol})$ and the resulting mixture was stirred at $110^{\circ} \mathrm{C}$ for 29 hours. The solution was cooled to room temperature, diluted with ethyl acetate $\left(20 \mathrm{~cm}^{3}\right)$, filtered and the filtrate was washed with $2 \mathrm{M} \mathrm{HCl}$ $\left(3 \times 20 \mathrm{~cm}^{3}\right)$ and the aqueous phase back extracted with ethyl acetate $\left(3 \times 30 \mathrm{~cm}^{3}\right)$. The combined organic layer was dried $\left(\mathrm{MgSO}_{4}\right)$ and the solvent was evaporated in vacuo. Purification by column chromatography (eluent i-hexaneethyl acetate 3:2, $40 \mathrm{~g}$ silica gel 40-60 $\mu \mathrm{m}$ mesh, 35x1.8 
$\mathrm{cm})$ to leave the title compound $4 \mathrm{e}(630 \mathrm{mg}, 39 \%)$ as a yellow oil.

\section{Method B}

To a solution of exo-7-oxohimic acid anhydride (1.00 $\mathrm{g}, 6.01 \mathrm{mmol})$ and $\mathrm{Et}_{3} \mathrm{~N}\left(2.00 \mathrm{~cm}^{3}, 14.0 \mathrm{mmol}\right)$ dissolved in toluene $\left(50 \mathrm{~cm}^{3}\right)$ was added $(S)$-aspartic acid diethyl ester hydrochloride $(1.58 \mathrm{~g}, 7.00 \mathrm{mmol})$ and the resulting mixture was stirred at $110^{\circ} \mathrm{C}$ for 56 hours. The solution was cooled to room temperature, diluted with ethyl acetate $\left(20 \mathrm{~cm}^{3}\right)$ and filtered. The filtrate was evaporated in vacuo and the residue purified by column chromatography (eluent chloroform-methanol 12:1, $50 \mathrm{~g}$ silica gel 40-60 $\mu \mathrm{m}$ mesh, $35 \times 2 \mathrm{~cm})$ to give the title compound $4 \mathrm{e}(1.00 \mathrm{~g}, 62 \%)$ as a yellow oil, $[\alpha]_{\mathrm{D}}^{2 \mathrm{~S}}=-15.6^{\circ}\left(\mathrm{c}=0.16, \mathrm{CH}_{2} \mathrm{Cl}_{2}\right)$.

\section{Method C}

To a solution of maleic anhydride $(1.00 \mathrm{~g}, 10.19 \mathrm{mmol})$ and $\mathrm{Et}_{3} \mathrm{~N}\left(2.11 \mathrm{~cm}^{3}, 15.00 \mathrm{mmol}\right)$ dissolved in toluene (50 $\left.\mathrm{cm}^{3}\right)$ was added (S)-aspartic acid diethyl ester hydrochloride $(2.48 \mathrm{~g}, 11.00 \mathrm{mmol})$ and the resulting mixture was stirred at $110^{\circ} \mathrm{C}$ for 44 hours. The solution was cooled to room temperature, diluted with ethyl acetate $\left(20 \mathrm{~cm}^{3}\right)$ and filtered. The filtrate was evaporated in vacuo, and the residue purified by column chromatography (eluent chloroform-methanol 12:1, $70 \mathrm{~g}$ silica gel 40-60 $\mu \mathrm{m}$ mesh, $80 \times 2 \mathrm{~cm})$ to give the title compound $4 \mathbf{e}(1.3 \mathrm{~g}, 55 \%)$ as a yellow oil, $[\alpha]_{\mathrm{D}}^{2 \mathrm{~b}}=-16.0^{\circ}\left(\mathrm{c}=0.15, \mathrm{CH}_{2} \mathrm{Cl}_{2}\right)$.

${ }^{1} \mathrm{H} \quad \mathrm{NMR} \quad\left(300 \quad \mathrm{MHz}: \mathrm{CDCl}_{3}\right) \quad 1.23 \quad(6 \mathrm{H}, \quad \mathrm{t}, \mathrm{t}, \quad 2 \mathrm{x}$ $\left.\mathrm{OCH}_{2} \mathrm{CH}_{3}\right), 3.03\left(1 \mathrm{H}, \mathrm{dd}, J 16.7,9.2 \mathrm{~Hz}, \mathrm{CH}_{2}\right), 3.25(1 \mathrm{H}$, dd, $\left.\mathrm{CH}_{2}\right), 4.16\left(4 \mathrm{H}, \mathrm{q}, \mathrm{q}, 2 \mathrm{x} \mathrm{OCH}_{2} \mathrm{CH}_{3}\right), 5.18(1 \mathrm{H}, \mathrm{dd}, J$ 9.2, 5.8 Hz, N-CH), $6.76(2 \mathrm{H}, \mathrm{s},=\mathrm{CH})$.

${ }^{13} \mathrm{C}$ NMR (300 MHz $\left.\mathrm{CDCl}_{3}\right) 14.01\left(\mathrm{q}, \mathrm{OCH}_{2} \mathrm{CH}_{3}\right)$, 14.10 (q, $\left.\mathrm{OCH}_{2} \mathrm{CH}_{3}\right), 33.98\left(\mathrm{t}, \mathrm{CH}_{2}\right), 48.34(\mathrm{~d}, \mathrm{~N}-\mathrm{CH})$, $61.08\left(\mathrm{t}, \mathrm{OCH}_{2} \mathrm{CH}_{3}\right), 62.35\left(\mathrm{t}, \mathrm{OCH}_{2} \mathrm{CH}_{3}\right), 134.38(\mathrm{~d}$, $=\mathrm{CH}), 168 . \mathrm{O} 8,169.61,169.93(\mathrm{~s}, \mathrm{C}=\mathrm{O})$.

\section{$N$-Maleonyl-(S)-tryptophane-methyl ester $4 f$}

\section{Method B}

To a solution of exo-7-oxohimic acid anhydride (502 $\mathrm{mg}, 3.00 \mathrm{mmol})$ and $\mathrm{Et}_{3} \mathrm{~N}\left(0.83 \mathrm{~cm}^{3}, 6.00 \mathrm{mmol}\right)$ dissolved in toluene $\left(40 \mathrm{~cm}^{3}\right)$ was added (S)-tryptophane methyl ester hydrochloride $(890 \mathrm{mg}, 3.50 \mathrm{mmol})$ and the resulting mixture was stirred at $110^{\circ} \mathrm{C}$ for 24 hours. The solution was cooled to room temperature, diluted with ethyl acetate $\left(20 \mathrm{~cm}^{3}\right)$ and filtered. The filtrate was evaporated in vacuo, and the residue purified by column chromatography (eluent i-hexane-ethyl acetate 1:2, $30 \mathrm{~g}$ silica gel 40-60 $\mu \mathrm{m}$ mesh, $35 \times 2 \mathrm{~cm})$ to give the title compound $\mathbf{4 f}(453 \mathrm{mg}, 50 \%)$ as a yellow oil, which solidified on standing. $[\alpha]_{\mathrm{D}}^{25}=-143.6^{\circ}$ (c $=0.11, \mathrm{CH}_{2} \mathrm{Cl}_{2}$ ).
${ }^{1} \mathrm{H}$ NMR (300 MHz; $\left.\mathrm{CDCl}_{3}\right) 3.62(2 \mathrm{H}, \mathrm{dd}, J$ 9.8, $\left.3.8 \mathrm{~Hz}, \mathrm{CH}_{2}\right), 3.75\left(3 \mathrm{H}, \mathrm{s}, \mathrm{OCH}_{3}\right), 5.04(1 \mathrm{H}, \mathrm{dd}, J$ 9.6, $6.7 \mathrm{~Hz}, \mathrm{~N}-\mathrm{CH}), 6.50(2 \mathrm{H}, \mathrm{s},=\mathrm{CH}), 6.88(1 \mathrm{H}, \mathrm{d}, J 1.83 \mathrm{~Hz}$, $=\mathrm{CH}-\mathrm{N}), 7.05$ (2H, m, Harom.), 7.21 (1H,d, J 7.68, Harom.), 7.50 (1H, d, Harom.), 8.23 (1H, s, NH).

${ }^{13} \mathrm{C} \mathrm{NMR}\left(300 \mathrm{MHz} ; \mathrm{CDCl}_{3}\right) 24.59\left(\mathrm{t}, \mathrm{CH}_{2}\right), 52.67(\mathrm{~d}$, $\mathrm{N}-\mathrm{CH}), 52.86\left(\mathrm{q}, \mathrm{OCH}_{3}\right), 110.59,111.31,118.34,119.48$, 122.04, 122.78, 127.05, 136.05 (Carom.), 134.89 (d, =CH), 169.64 (s, C=O), 170.00 (s, C=O).

\section{1,3-Dipolar cycloaddition of 2,4,6-trimethylphenylnitrile oxide to maleimide $\mathbf{4 a - e}$}

The nitrile oxide $(0.4 \mathrm{mmol})$ was stirred with maleimide $4 a-f$ in $5 \mathrm{~cm}^{3}$ benzene at $80^{\circ} \mathrm{C}$ The reaction was controlled by TLC. After completion of this reaction the solution was evaporated and a sample for NMR was carried out.

\section{1,3-Dipolar cycloaddition of phenylnitrile oxide to maleimide $4 c, e$}

Triethylamine $\left(0.16 \mathrm{~cm}^{3}, 1.2 \mathrm{mmol}\right)$ in anhydrous ether $\left(20 \mathrm{~cm}^{3}\right)$ was added during 24 hours to a stirred and cooled $\left(0-5^{\mathrm{c}} \mathrm{C}\right.$, salt-ice bath) solution of maleimide $(1.0 \mathrm{mmol})$ and bezhydroxymoyl chloride $(1.2 \mathrm{mmol})$ in anhydrous ether $\left(25 \mathrm{~cm}^{3}\right)$. The resulting reaction mixture was allowed to stir for 7 days at room temperature. After this time the reaction mixture was filtered, the solution was evaporated to dryness and a sample for NMR was carried out.

Acknowledgement: The authors are grateful to the Slovak Grant Agency for receiving financial support No. 1/1416/94 and the VW-Stiftung in Hannover for a research grant and receiving financial support.

\section{References}

1. Corrie, J. E. T. J. Chem. Soc. Perkin Trans. 1 1994, 2975.

2. Janda, K. D.; Ashley, J. A.; Jones, T. M.; McLeod, D. A.; Schloeder, D. M.; Weinhouse M. I. J. Am. Chem. Soc. 1990, 112, 8886.

3. Matocsy, G.: Nadasi, M.: Adriska V. Pesticide Chemistry, Akademiai Kiadó, Budapest 1988.

4. Fujinami, A.: Ozaki,T.: Nodera, K.; Tanaka, K. Agric. Biol. Chem. 1972, 36, 318.

5. Tottori, N.: Ueda, M.: Kirino, O.: Oba ,S.: Fujinami, A.; Kato, T.; Ozaki, T. Japan Kokai 74124225. Chem. Abst. 1975, 82, 150501.

6. Grigg, R.; Surendrakumar, S.; Thianpatanagul, S.; Vipond, D. J. J. Chem. Soc. Perkin Trans. 1 1988, 2693.

7. Baldwin, S. W.: Greenspan, P.: Alaimo, C.: McPhail, A.T. Tetrahedron Lett. 1991, 32, 5877. 
8. Konopíková, M.; Fisera, L.; Prónayová, N. Collect. Czech. Chem. Commun. 1991, 57, 1521.

9. Searle N. E. U. S. Pat. 2444536 (1948), Chem. Abst. 1948, 42, 7340.

10. Biagini, S. C. G.: Bush, S. M.; Gibson, V. C.; Mazzariol, L.: North, M.; Teasdale, W. G.: Williams, C. M.: Zagotto, G.; Zamuner, D. Tetrahedron 1995, $51,7247$.
11. Tochtermann, W.: Bruhu, S.: Wolff, C. Tetrahedron Lett. 1994, 35, 1165.

12. Grundmann, C.: Dean, M. J. J. Org. Chem. 1965, 30, 2809.

Sample Availability: Available from the authors. 